\title{
Studying the Effect of New Didactic Tool on the Effectiveness of Educational Activity
}

\author{
Irina Yurievna Glazkova ${ }^{1 *}$, Tatiana Mikhailovna Litvinova ${ }^{1}$, Olga Mikhailovna Kolomiets ${ }^{1}$, Olga Alexandrovna \\ Smyslova ${ }^{1}$
}

${ }^{1}$ Sechenov First Moscow State Medical University, Trubetskaya St., 8, Bldg. 2, Moscow, 119991, Russian Federation

*Corresponding author E-mail: glazkova.i.yu@mail.ru

\begin{abstract}
This article presents the results of studies devoted to assessing the survival of students' knowledge, regardless of their basic training. The study was conducted based on two groups of specialists, recertified under the program "Pharmacy management and economics" at the Pharmacy Department of Sechenov First Moscow State Medical University. Some of the specialists of the experimental groups had been previously trained at the Pharmacy Department of Sechenov First Moscow State Medical University in 2012-2013 using a new developed didactic tool named "Activity Book". According to the results obtained, the skills acquired by the specialists trained using on "Activity Book" in 2012-2013, were characterized by higher "survivability".
\end{abstract}

Keywords: Didactic tool; Educational process; efficiency of educational activity.

\section{Introduction}

A system-based approach to learning opens up a new vision of the structure of practical activity. Components of transformation activity are not separate stages, through which the process of solving practical problems is constructed; the system-based education components (indicative, planning, performing, monitoring, evaluating, and correcting) are interrelated by backbone connections. Because of this, none of them can be missed for one reason or another when constructing practical activities; each of them performs a certain function, has its own substantive content, and occupies a certain place in the structure of activities when solving a practical problem [1-3].

Existing activity books usually contain only a list of practical assignments and tasks aimed at developing new knowledge. It is assumed that before starting working with an activity book, students should already have the knowledge, which needs to be applied in the course of solving practical problems of the activity book. That is, the stage of independent work with primary sources, when a student uncovers, produces new knowledge, is missed. The existing didactic materials are a simple set of practical tasks and assignments without a systematic framework, with no regard to the structural stages of a student's educational activity $[4,5]$.

Since a training activity involves a certain sequence of actions, the loss of even one of its components can lead to the destruction of the entire structure.

Therefore, those practical tasks that are given in different activity books do not focus on the formation of holistic learning activities. They just offer a list, a collection of tasks without a systematic framework, and without connection with specific stages of the learning process. An activity book should model the educational and research activities of a specialist when working with primary sources, with text material, producing new knowledge, processing information which is selected from the primary source, and sche- matizing this information. Only then this information becomes real subjective knowledge of a student [6].

Thus, there is a need to create an activity book that would meet today's didactic, scientific, and pedagogical requirements. In 2012, the authors developed a new didactic tool, which was called "Activity Book" (AB) [7].

The use of theoretical aspects of activity- and system-based approaches to training gives new opportunities when developing $A B$. The concerned didactic tool is characterized by the following main features: new characteristics of knowledge to be assimilated; a new representation form of training activities; the inclusion of methodological knowledge along with certain subject-specific comprehensible knowledge; generalization and systematization of new knowledge in the orientation schemes of the systematic type (variety of reference tables and reference maps) produced during teaching and research activities; the inclusion of materials' module aimed at the formation in a specialist of theoretical reflection of performed research and practical activities.

Working with such $\mathrm{AB}$, a student constructs his/her educational activity in writing and oral forms first with the teacher, and then independently. In addition to the assimilation of specific subject material of the training module, $\mathrm{AB}$ organizes the assimilation by a specialist of learning technology of a particular discipline. A student acquires methodological knowledge and skills to build an independent learning activity on the assimilation of the studied material on a particular topic. Thus, organizing educational and research activities of a specialist, $\mathrm{AB}$ teaches him/her to "learn independently on his/her own" and prevents possible mistakes.

The developed didactic materials create conditions to form a new mental state in every specialist, namely "position of the learner", where he/she himself/herself without the help of anyone: 1) knows how to learn; 2) wants to learn; 3) really studies based on the "ability to learn", formed de facto.

Preparation of such materials requires a high level of methodological competence of the teacher, a careful selection of the whole material, etc. [8-10]. 


\section{Methods}

The methods of logical, sociological, situational, and statistical analysis were used in the course of the conducted research.

\section{Results and Discussion}

The experiment was carried out from January to June 2018 involving students of the advanced training course "Pharmacy management and economics" (144 learning hours). All specialists working in the healthcare system in pharmacy organizations undergo advanced training every 5 years. The period of specialists' certification, who studied at the Pharmacy Department of Sechenov First Moscow State Medical University in 2012-2013, expired in January, and $\mathrm{AB}$ was implemented into educational process for the first time exactly during this period.

The study included two groups of specialists, who were undergoing recertification under the "Pharmacy management and economics" program.

The first group included 19 specialists, among whom 10 specialists (group 1A) studied according to AB at the Pharmacy Department of Sechenov First Moscow State Medical University in 2012-2013, while 9 specialists were trained in other educational institutions in the period of 2012-2013 (group 1B)

The second group included 15 specialists among whom 8 specialists (group 2A) studied according to AB at the Pharmacy Department of Sechenov First Moscow State Medical University in 2012-2013, while 7 specialists (group 2B) were trained in other educational institutions in the period of 2012-2013.

Table 1 presents the data on the performance of individual tasks in the tested groups.

Table 1: Results on the performance of individual tasks in the tested groups

\begin{tabular}{|c|c|c|c|c|c|}
\hline & \multirow{2}{*}{$\begin{array}{c}\text { Number of } \\
\text { Group }\end{array}$} & \multicolumn{5}{|c|}{ Number of students, who had performed individual } \\
stusk pe & \multicolumn{5}{|c|}{$\%$} \\
\cline { 3 - 6 } & group & Test No. 1 & Test No. 2 & Task No. 1 & Task No. 2 \\
\hline 1A & 10 & 90 & 90 & 100 & 90 \\
\hline 1B & 9 & 88 & 77 & 66 & 66 \\
\hline 2A & 8 & 87 & 100 & 87 & 100 \\
\hline 2B & 7 & 85 & 100 & 85 & 72 \\
\hline
\end{tabular}

From the data presented in Table 1, it can be seen that the specialists included in the test groups $1 \mathrm{~A}$ and $2 \mathrm{~A}$ demonstrated better knowledge of the specific material, as well as the ability to solve quasi-clinical problems as compared to the specialists in groups $1 \mathrm{~B}$ and $2 \mathrm{~B}$. Special attention should be paid to the fact that the skills acquired by the students in groups $1 \mathrm{~A}$ and $2 \mathrm{~A}$ were characterized by higher "survivability" due to the previous use in the educational process of the new didactic tool.

\section{Conclusion}

The practice of conducting experimental work on the organization of the educational process based on the developed didactic materials for different educational modules results in an increase in students' performance and improves their psychological comfort throughout the educational process. In addition, the learning process becomes adaptive, accessible to a specialist, regardless of his/her individual abilities and characteristics, personal level of development, and the degree of his/her preparedness for a particular subject. In consequence, every specialist improves the quality of formed competencies.

The organization of the educational process on the basis of the developed $\mathrm{AB}$ will allow any specialist to develop the ability to reveal the structure and content of any practical task, as well as change qualitatively his/her professional activity. All of this will further increase the comprehensibility of students' knowledge regardless of their basic education. Along with pharmaceutical knowledge and skills, specialists will acquire the "ability to learn" during the whole professional life.

\section{References}

[1] Belogurova VA (2003), Nauchnaya organizaciya uchebnogo processa [Scientific organization of educational process]. Textbook for postgraduate education students. Moscow: Medicine.

[2] Galperin PYa (1966), Psihologiya myshleniya i uchenie o poehtapnom formirovanii umstvennyh dejstvij [Thinking psychology and the doctrine of the gradual formation of mental actions]. Studies of thinking in Soviet psychology. Moscow: Nauka, 236-277.

[3] Galperin PYa (2003), Psihologiya kak ob"ektivnaya nauka [Psychology as an objective science]. Ed. A.I. Podolsky. Moscow: Publishing House of the Moscow Psychological and Social Institute.

[4] Reshetova ZA (2002), Formirovanie sistemnogo myshleniya $v$ obuchenii [Formation of systematic thinking in education]. Moscow: Unity, 219-236.

[5] Zmeev SI (2007), Andragogika: osnovy teorii, istorii i tekhnologii obucheniya vzroslyh [Andragogy: Fundamentals of theory, history and adult education technology]. Moscow: PER SE.

[6] Integraciya metodicheskoj raboty i sistemy povysheniya kvalifikacii kadrov [Integration of methodical work and professional development system]. Proceedings of the X All-Russian science-topractice conference. Part 6, Moscow-Chelyabinsk, 2009, pp. 107 112.

[7] Litvinova TM, Glazkova IU, Kolomiets OM, Smyslova OA \& Denisova MN (2017), Using case method in organizing student academic/professional activity as part of the educational process. Espacios 38(56), 291-305.

[8] Reshetova ZA \& Samonenko YuA (1982), Sistemnyj tip orientirovki v predmete i ehvristicheskie vozmozhnosti uchashchihsya [Systematic type of orientation in the subject and heuristic possibilities of students]. Bulletin of the Moscow State University 24(1), Psychology, 20-29.

[9] Talyzina NF (1986), Teoreticheskie osnovy razrabotki modeli specialista [Theoretical bases of specialist model development]. Moscow.

[10] Reshetova ZA (2002), Formirovanie sistemnogo myshleniya $v$ obuchenii [Formation of systematic thinking in training]. Study guide for higher education institutions. Moscow: Unity. 